\title{
Screen Graphene-printed Electrode for Trace Cadmium Detection in Rice Samples Combing with Portable Potentiostat
}

\author{
Yuanjie Teng "Yuchao Zhang, Kai Zhou, Zhengxiang Yu
}

State Key Laboratory Breeding Base of Green Chemistry-Synthesis Technology, College of Chemical Engineering, Zhejiang University of Technology, Hangzhou 310014, Zhejiang Province, P. R. China

*E-mail: yuanjieteng@zjut.edu.cn

doi: $10.20964 / 2018.07 .61$

Received: 7 March 2018 / Accepted: 8 May 2018 / Published: 5 June 2018

\begin{abstract}
A disposable screen graphene-printed electrode (SGPE) was developed by directly printing the prepared graphene paste on the surface of screen-printed carbon working electrode, and a differential pulse stripping voltammetry (DPV) method combing with portable potensiostat were introduced to the rapid detection of trace $\mathrm{Cd}^{2+}$ in rice samples. The surface morphology of SGPE was characterized by scanning electron microscope, and the graphene structure and its electrochemical activity were confirmed by Raman spectroscopy and cyclic voltammetry. Results showed that SGPE presents better conductivity than screen-printed carbon electrode or glass carbon electrode. The pre-concentration potential and time were optimized as $-1.5 \mathrm{~V}$ and $500 \mathrm{~s}$. And a pH 8.2 basic buffer was selected because $\mathrm{OH}^{-}$did not pose an interference $\left(\mathrm{K}_{\mathrm{sp}}\right.$ of $\left.\mathrm{Cd}(\mathrm{OH})_{2}=2.5 \times 10^{-14}\right)$ and show a good stripping current signal. The obtained results from portable potentiostat were similar to the results obtained by inductively coupled plasma mass spectrometry (ICP-MS). Therefore, the proposed SGPE and its effectively analytical method could be further improved for the realization of an ideally rapid on-site detector for trace $\mathrm{Cd}^{2+}$ detection in rice samples.
\end{abstract}

Keywords: screen graphene-printed electrode; cadmium; portable potentiostat; differential pulse stripping voltammetry; rice samples

\section{FULL TEXT}

(C) 2018 The Authors. Published by ESG (www.electrochemsci.org). This article is an open access article distributed under the terms and conditions of the Creative Commons Attribution license (http://creativecommons.org/licenses/by/4.0/). 